\title{
Development of macronutrient composition of very preterm human milk
}

\author{
Yolanda G. H. Maas ${ }^{1}$, Jeanet Gerritsen ${ }^{1}$, Augustinus A. M. Hart ${ }^{2}$, Mijna Hadders-Algra ${ }^{3}$, \\ Jan M. Ruijter ${ }^{4}$, Pieter Tamminga ${ }^{1}$, Majid Mirmiran ${ }^{5}$ and Henk Spekreijse ${ }^{4}$ \\ ${ }^{1}$ Department of Neonatology and ${ }^{2}$ Department of Clinical Epidemiology and Biostatistics, Academic Medical Center, \\ University of Amsterdam, Emma Childrens' Hospital, PO Box 22700, 1100 DE Amsterdam, The Netherlands \\ ${ }^{3}$ Department of Medical Physiology, University of Groningen, Bloemsingel 10, 9712 KZ Groningen, The Netherlands \\ ${ }^{4}$ The Netherlands Ophthalmic Research Institute and Laboratory of Medical Physics, PO Box 12141, \\ 1100 AC Amsterdam, The Netherlands \\ ${ }^{5}$ Netherlands Institute for Brain Research, Meibergdreef 33, 1105 AZ Amsterdam, The Netherlands
}

(Received 24 July 1997 - Revised 8 January 1998 - Accepted 27 January 1998)

\begin{abstract}
The effects of gestational age at delivery (GA), postnatal age (PNA) and post-menstrual age $(\mathrm{PMA}=\mathrm{PNA}+\mathrm{GA}$, an indicator of autonomous developmental processes not affected by the moment of birth) on macronutrient composition of very preterm milk were studied. Total $\mathrm{N}$, fat, lactose and carbohydrate concentrations, energy density and $24 \mathrm{~h}$ volume were determined in 282 $24 \mathrm{~h}$ milk samples collected at weekly intervals (days 7-55 of lactation) from seventy-nine women delivering their babies between 25 and 29 weeks of gestation. GA related differences were found for carbohydrate concentration only: carbohydrate concentration was lower with increasing GA. PNA was related to a decrease in total $\mathrm{N}$ and an increase in lactose concentration. PMA was not related to milk composition. Our data indicate that PNA strongly influences the development of the composition of very preterm human milk, while GA affects carbohydrate content with a negligible effect on the nutritional value of the milk. We conclude that in accordance with current opinion in paediatrics, human milk is the best source of nutrients even for very preterm $(<30$ weeks GA) infants.
\end{abstract}

Human milk: Preterm infant: Development

Human milk has long been recommended as the ideal nutrient source for full-term neonates, but there is still controversy concerning its suitability for the preterm infant (Lawrence, 1994). Most studies comparing the macronutrient composition of preterm human milk with full-term human milk found a difference in composition, with preterm milk having a higher $\mathrm{N}$ content and a higher nutritional value than full-term milk (Atkinson et al. 1978, 1980; Gross et al. 1980, 1981; Schanler \& Oh, 1980; Anderson et al. 1981; Guerrini et al. 1981; Lemons et al. 1982, 1983; Butte et al. 1984; Lepage et al. 1984; Darwish et al. 1989; Dawodu et al. 1990). These findings gave rise to the common consent that when a mother gives birth prematurely her milk is more suitable for her child than full-term milk. It is also known that the composition of milk shows considerable differences with the stage of lactation (Hytten, 1954; Atkinson et al. 1978, 1980; Gross et al. 1980; Anderson et al. 1981; Hibberd et al. 1982; Anderson et al. 1983; Butte et al. 1984; Pierse et al. 1988; Jain \& Bijlani, 1989; Lawrence, 1994).

The underlying factors producing the differences in composition and the mechanisms leading to the patterns of change in composition are still unclear. In the present study we have examined the influence of gestational age at delivery (GA) and duration of lactation (postnatal age; PNA) and, when indicated, of post-menstrual age (PMA; GA + PNA) on the changing macronutrient composition of preterm milk in a group of mothers giving birth before 30 weeks of gestation. Mathematically, PMA is the simple addition of GA and PNA, but developmentally PMA is an independent time measure, reflecting endogenouslygenerated maturational processes from conception onwards (Prechtl, 1984). As the moment of conception usually is uncertain, it is common practice to use PMA for documenting developmental age.

\section{Materials and methods}

\section{Milk donors}

Milk samples ( $n$ 311) were obtained at weekly intervals from seventy-nine mothers giving birth before 30 weeks of 
gestation and who had the intention to breast-feed their infants. GA was determined by the first day of the last menstrual period of the mother. This was confirmed either by an ultrasound examination during early pregnancy or a maturational assessment of the preterm infant with the help of the Dubowitz score (Dubowitz et al. 1970). Thirteen mothers gave birth in the 25th or 26th week of gestation, twenty mothers in the 27th week, twenty-one mothers in the 28th week and twenty-five mothers in the 29th week.

The study protocol was approved by the Medical Ethical Committee of the Academic Medical Center, Amsterdam.

\section{Collection of milk samples}

The collection of the $24 \mathrm{~h}$ samples started as soon as there was sufficient milk to both feed the child and take a $25 \mathrm{ml}$ sample for analysis. Samples were taken for as long as the infant stayed in the hospital and milk production was adequate. Mothers pumped their breasts manually or mechanically, collecting the milk in sterile (deionized) bottles. The number and duration of expressions of milk varied per mother, according to their own habit. All expressions of milk were pooled over $24 \mathrm{~h}$, mixed thoroughly and the volume was measured. All samples were stored at $-20^{\circ}$ until analysed.

\section{Chemical analysis}

Total $\mathrm{N}$ concentration $(\mathrm{mg} / \mathrm{kg})$ was determined using Kjeldhal analysis (Helrich, 1990). Crude protein was calculated by multiplying Kjeldhal $\mathrm{N}$ by $6 \cdot 38$. Fat $(\mathrm{g} / \mathrm{kg})$ was determined according to the method of Roese-Gottlieb (Helrich, 1990). Lactose $(\mathrm{g} / \mathrm{kg})$ was determined using an enzymic procedure (Boerhinger Mannheim GmbH, 1989). Carbohydrate $(\mathrm{g} / \mathrm{kg})$ was calculated as:

$$
\text { carbohydrate }=\mathrm{DM}-\text { protein }- \text { fat }- \text { ash, }
$$

DM being determined as the mass left after rotary evaporation at $102^{\circ}$ and ash being determined as the mass left after heating at $550^{\circ}$ (Helrich, 1990). Gross total energy content $(\mathrm{kJ} / \mathrm{kg})$ was calculated as:

$$
\begin{aligned}
\text { energy }=(\text { protein } & \times 5.65+\text { fat } \times 9.25+\text { carbohydrate } \\
& \times 3.95) \times 4.18,
\end{aligned}
$$

with protein, fat and carbohydrate expressed in $\mathrm{g} / \mathrm{kg}$ milk and the constants expressed in $\mathrm{kcal} / \mathrm{g} ; 4.18$ being the factor used to convert values to $\mathrm{kJ}$ (Anderson et al. 1981).

\section{Statistical analysis}

To evaluate the effects of GA, PNA or PMA on the macronutrient composition of very premature human milk, unbalanced repeated-measurements analysis of covariance with structured covariance matrices was performed (BMDP $5 \mathrm{~V}$; Dixon, 1992). This technique allows for missing data which are estimated implicitly from the available data. Only $24 \mathrm{~h}$ samples taken before $56 \mathrm{~d}$ of lactation ( $n$ 282) were used in the statistical analysis, as the older lactational ages lacked sufficient samples for reliable statistics. PMA being the same as GA + PNA makes it impossible to analyse all three effects (PNA, PMA and GA) in one model. Thus, analysis of the effects of GA and PNA was first performed for each nutrient and energy density using the following model:

$$
\begin{gathered}
\text { nutrient or energy density }=\mathrm{GA}+\mathrm{PNA} \\
+24 \mathrm{~h} \text { volume effect, }
\end{gathered}
$$

and for $24 \mathrm{~h}$ volume using the model:

$$
24 \mathrm{~h} \text { volume }=\mathrm{GA}+\text { PNA. }
$$

When a statistically significant $(P<0.05)$ effect of GA was found in this model, PNA was replaced by PMA in order to decide whether the combined effect of GA and PNA could be explained by a single effect of PMA. This would be the case if GA lost its significance in the PMA model. If GA remained significant in this model as well, this was seen as an indication of an independent effect of GA. Time scales of PNA and PMA were both divided into eleven time intervals, for PNA between days 7 and 55 (interval 4-5d) and for PMA between days 183 and 258 (interval $7 \mathrm{~d}$ ). GA was used as a between-mother grouping variable with four categories: 25-26 weeks, 27 weeks, 28 weeks and 29 weeks. The $24 \mathrm{~h}$ milk volume was used as a time-varying covariate in the nutrient and energy density analysis.

To test the assumptions of the model and to check for outliers, analysis of residuals was performed from the unbalanced repeated measurements analysis. When indicated, a Box-Cox (1964) transformation was applied and the effect of outliers was analysed. When a significant overall effect of GA or time was found, a test of which groups or periods differed was performed by calculating contrasts.

\section{Results \\ $24 \mathrm{~h}$ milk volume}

Based on the residual analysis this variable was log transformed. The amount of milk produced by the mothers during a $24 \mathrm{~h}$ period was not found to be related to GA or PNA (Tables 1-3).

\section{Total nitrogen}

Changes in total $\mathrm{N}$ were related to PNA; an increase in PNA was associated with a significant decrease in total $\mathrm{N}$ content (Tables 1-3). Moreover, total $\mathrm{N}$ content was related to $24 \mathrm{~h}$ milk volume; an increase in $24 \mathrm{~h}$ milk volume of $100 \mathrm{ml}$ was associated with a decrease in total $\mathrm{N}$ content of 8 (SE 2) $\mathrm{mg}$.

\section{Fat}

Fat content was not found to be related to GA or PNA (Tables $1-3$ ), nor was it found to be affected by $24 \mathrm{~h}$ milk volume.

\section{Lactose}

Based on the residual analysis this variable was transformed using the exponent 2.5. Lactose content was not found to be 
Table 1. Milk volume $(24 \mathrm{~h})$ and macronutrient composition of preterm human milk for eleven postnatal periods (range 7-55 d)

(Values are means and standard deviations)

\begin{tabular}{|c|c|c|c|c|c|c|c|c|c|c|c|c|c|c|}
\hline \multirow[b]{2}{*}{ Postnatal period } & \multirow[b]{2}{*}{ Postnatal age (d) } & \multirow[b]{2}{*}{$n$} & \multicolumn{2}{|c|}{$\begin{array}{l}\text { Volume } \\
\text { (ml/24 h) }\end{array}$} & \multicolumn{2}{|c|}{$\begin{array}{l}\text { Total N } \\
(\mathrm{g} / \mathrm{kg})\end{array}$} & \multicolumn{2}{|c|}{$\begin{array}{l}\text { Fat } \\
(\mathrm{g} / \mathrm{kg})\end{array}$} & \multicolumn{2}{|c|}{$\begin{array}{l}\text { Lactose } \\
(\mathrm{g} / \mathrm{kg})\end{array}$} & \multicolumn{2}{|c|}{$\begin{array}{l}\text { Carbohydrate } \\
(\mathrm{g} / \mathrm{kg})\end{array}$} & \multicolumn{2}{|c|}{$\begin{array}{l}\text { Energy } \\
(\mathrm{kJ} / \mathrm{kg})\end{array}$} \\
\hline & & & Mean & SD & Mean & $\mathrm{SD}$ & Mean & SD & Mean & SD & Mean & SD & Mean & SD \\
\hline 2 & $11-14$ & 31 & 261 & 201 & 3.0 & 0.6 & 34.9 & 10.5 & 55.9 & $6 \cdot 1 \dagger$ & 71.5 & 6.2 & 2988 & 419 \\
\hline 3 & $15-19$ & 32 & 391 & 255 & $2 \cdot 6$ & 0.6 & 34.0 & $5 \cdot 7$ & 58.9 & 5.2 & 74.3 & 4.2 & 2930 & 263 \\
\hline 4 & $20-23$ & 35 & 329 & 253 & 2.5 & 0.5 & 33.9 & 7.5 & $57 \cdot 6$ & 4.7 & 72.5 & 4.7 & 2885 & 361 \\
\hline 8 & $38-41$ & 16 & 264 & 243 & 2.4 & 0.5 & 31.7 & $8 \cdot 7$ & $57 \cdot 1$ & $6 \cdot 6$ & 70.4 & 5.5 & 2749 & 334 \\
\hline 9 & $42-46$ & 18 & 454 & 247 & $2 \cdot 1$ & 0.3 & 35.7 & 4.4 & $61 \cdot 8$ & 3.0 & $75 \cdot 0$ & 3.5 & 2933 & 195 \\
\hline 10 & $47-50$ & 12 & 366 & 281 & 2.0 & 0.5 & 33.3 & 5.4 & 59.5 & $5 \cdot 1$ & $72 \cdot 7$ & 5.1 & 2786 & 210 \\
\hline 11 & $51-55$ & 9 & 348 & 204 & $2 \cdot 0$ & 0.3 & 32.7 & 6.4 & 61.9 & $2 \cdot 1$ & $72 \cdot 9$ & 4.2 & 2774 & 274 \\
\hline all & $7-55$ & 282 & 329 & $231 \S$ & 2.5 & 0.6 & 34.3 & $7.3 \S$ & 58.2 & $5.4 \S$ & 73.0 & $4.9 \S$ & 2914 & $329 \S$ \\
\hline
\end{tabular}

${ }^{*} n 35$

$+n 30$.

$\ddagger n 37$.

$\S n 281$.

Table 2. Milk volume $(24 \mathrm{~h})$ and macronutrient composition of preterm human milk for eleven post-menstrual periods (range $183-258 \mathrm{~d}$ )

(Values are means and standard deviations)

\begin{tabular}{|c|c|c|c|c|c|c|c|c|c|c|c|c|c|c|}
\hline \multirow{2}{*}{$\begin{array}{l}\text { Post-menstrual } \\
\text { period }\end{array}$} & \multirow{2}{*}{$\begin{array}{l}\text { Post-menstrual } \\
\text { age (weeks) }\end{array}$} & \multirow[b]{2}{*}{$n$} & \multicolumn{2}{|c|}{$\begin{array}{l}\text { Volume } \\
\text { (ml/24 h) }\end{array}$} & \multicolumn{2}{|c|}{$\begin{array}{l}\text { Total N } \\
(\mathrm{g} / \mathrm{kg})\end{array}$} & \multicolumn{2}{|c|}{$\begin{array}{l}\text { Fat } \\
(\mathrm{g} / \mathrm{kg})\end{array}$} & \multicolumn{2}{|c|}{$\begin{array}{l}\text { Lactose } \\
(\mathrm{g} / \mathrm{kg})\end{array}$} & \multicolumn{2}{|c|}{$\begin{array}{l}\text { Carbohydrate } \\
(\mathrm{g} / \mathrm{kg})\end{array}$} & \multicolumn{2}{|c|}{$\begin{array}{l}\text { Energy } \\
(\mathrm{kJ} / \mathrm{kg})\end{array}$} \\
\hline & & & Mean & $S D$ & Mean & $\mathrm{SD}$ & Mean & SD & Mean & SD & Mean & SD & Mean & SD \\
\hline 2 & $27-28$ & 9 & 277 & $113^{*}$ & 3.2 & 0.7 & 34.4 & 7.5 & $55 \cdot 3$ & 3.8 & 74.7 & $4 \cdot 1$ & 3045 & 318 \\
\hline 3 & $28-29$ & 17 & 324 & 213 & 2.9 & 0.5 & 34.8 & 7.0 & 57.7 & 4.6 & 74.9 & 3.0 & 3012 & 304 \\
\hline 4 & $29-30$ & 36 & 310 & 206 & 2.9 & 0.7 & $36 \cdot 3$ & 9.3 & 55.9 & 7.1 & 72.4 & 5.4 & 3035 & 439 \\
\hline 7 & $32-33$ & 46 & 366 & 268 & $2 \cdot 3$ & 0.4 & 33.7 & 6.7 & 58.7 & 5.0 & 72.4 & 5.0 & 2838 & 284 \\
\hline 8 & $33-34$ & 32 & 364 & 269 & $2 \cdot 2$ & 0.4 & 34.0 & 6.5 & $60 \cdot 3$ & 4.4 & $73 \cdot 6$ & 4.7 & 2865 & 281 \\
\hline 9 & $34-35$ & 22 & 319 & 226 & 2.2 & 0.5 & 33.7 & $7 \cdot 3$ & 59.2 & $5 \cdot 1$ & $72 \cdot 3$ & $5 \cdot 1$ & 2822 & 327 \\
\hline 10 & $35-36$ & 11 & 390 & 238 & $2 \cdot 0$ & 0.4 & 34.3 & 6.0 & $60 \cdot 3$ & 3.8 & 71.8 & 3.9 & 2818 & 252 \\
\hline 11 & $36-37$ & 4 & 358 & 175 & $2 \cdot 1$ & 0.3 & 30.3 & 4.3 & 63.2 & $2 \cdot 1$ & 74.3 & 2.7 & 2714 & 178 \\
\hline all & $26-37$ & 282 & 329 & $231 \S$ & 2.5 & 0.6 & 34.3 & $7.3 \S$ & 58.2 & $5.4 \S$ & 73.0 & $4.9 \S$ & 2914 & $329 \S$ \\
\hline
\end{tabular}

$* n 8$.

$+n 49$.

$\ddagger n 53$.

$\S n 281$.

related to GA, but lactose content increased highly significantly with increasing PNA (Tables 1-3). Milk volume also affected lactose content; an increase in $24 \mathrm{~h}$ milk volume of $100 \mathrm{ml}$ was associated with an increase in lactose content of $0 \cdot 14$ (SE 0.02) g.

\section{Carbohydrate}

Based on the residual analysis this variable was transformed using the exponent 4.5. An effect of GA on total carbohydrate was found, mainly due to differences between carbohydrate content at 28 weeks of GA and both the carbohydrate contents at 25-26 and 27 weeks of GA (Table 4). A trend towards an effect of PNA on total carbohydrate content was found $(P=0.057$; Tables $1-3)$. Analysis of an effect of PMA was therefore indicated, confirming an independent effect of GA on carbohydrate while no effect of PMA was found. An increase in $24 \mathrm{~h}$ milk volume of $100 \mathrm{ml}$ was associated with an increase in total carbohydrate content of $0 \cdot 10$ (SE 0.02) g.

\section{Energy content}

Energy content was not found to be related to GA or PNA (Tables 1-3), nor was it found to be affected by $24 \mathrm{~h}$ milk volume.

\section{Discussion}

The present study, like others, showed that the composition of very preterm milk changes during lactation (Atkinson et al. 1980; Gross et al. 1980; Schanler \& Oh, 1980; Anderson et al. 1981; Pamblanco et al. 1986; Beijers et al. 1992). To explain the observed time effect we evaluated 
Table 3. Statistical significance ( $P$ values) of the effect of gestational age at delivery (GA), postnatal (PNA) or post-menstrual (PMA) age (if analysed) and $24 \mathrm{~h}$ milk volume on total nitrogen, fat, lactose, carbohydrate and energy content of $24 \mathrm{~h}$ milk (model a) and of the effect of GA and PNA on $24 \mathrm{~h}$ milk volume (model b), from mothers delivering preterm

(Statistical method was an unbalanced repeated-measurements analysis of covariance with structured covariance matrices using the models: (a) variable $=\mathrm{GA}+\mathrm{PNA}$ (or PMA) $+24 \mathrm{~h}$ volume effect, (b) $24 \mathrm{~h}$ volume effect $=\mathrm{GA}+\mathrm{PNA})$

\begin{tabular}{lccc}
\hline \multirow{3}{*}{ Variable } & \multicolumn{3}{c}{ Effect of: } \\
\cline { 2 - 4 } & $\mathrm{GA}$ & PNA (or PMA) & 24 h volume \\
\hline Total N & 0.85 & $<0.0001$ & $<0.0001$ \\
Fat & 0.25 & 0.69 & 0.31 \\
Lactose & 0.25 & $<0.0001$ & $<0.0001$ \\
Carbohydrate & 0.0065 & 0.057 & $<0.0001$ \\
& 0.013 & $0.71^{*}$ & $<0.0001$ \\
Energy & 0.45 & 0.011 & 0.15 \\
24 h volume & 0.95 & 0.89 & - \\
\hline
\end{tabular}

${ }^{*}$ Effect of PMA.

the effect of three time variables: PNA, GA and, a novelty, PMA. The major findings of our study are that developmental changes in milk composition are largely determined by PNA, minimally by GA and not at all by PMA. This means that the composition of preterm human milk is not determined by autonomous developmental processes related to the moment of conception, but that the maternal body adapts to the moment of precocious delivery. Milk volume (24h) itself did not show a dependence on GA, PNA or PMA. But using volume as a time-varying covariate in our analysis we found that total $\mathrm{N}$ content decreases while lactose and carbohydrate content increase when $24 \mathrm{~h}$ milk volume increases, which is in accordance with the literature (Atkinson et al. 1978; Gross et al. 1981; Lemons et al. 1982; Anderson et al. 1983). One should be aware of the limitation of our finding, i.e. no effect of PNA on $24 \mathrm{~h}$ milk volume. Factors such as stress of delivering extremely preterm infants, 'high-tech' neonatal intensive care units and the absence of breast-feeding all contributed to this finding.

\section{Statistical analysis}

The aim of our study was to get more insight into the patterns underlying the changes in nutrient concentration of preterm human milk, whereas other studies focused only on differences between milk obtained from mothers delivering their babies preterm $v$. term. In general, the statistical analysis of previous studies has been done on mean nutrient values of small numbers of mothers at different postnatal days (Schanler \& Oh, 1980; Guerrini et al. 1981; Anderson et al. 1983; Lemons et al. 1983; Lepage et al. 1984; Darwish et al. 1989; Dawodu et al. 1990), thereby ignoring the considerable variability in milk volume and nutrient concentration which exists between and within individual mothers, particularly in preterm mothers (Gross et al. 1981; Hibberd et al. 1982; Anderson, 1984). To allow correction for intra- and inter-individual variations we collected longitudinal data from a total of seventy-nine mothers and used unbalanced repeated measurement
Table 4. Total carbohydrate and lactose content of preterm human milk for four gestational age at delivery (GA) groups

(Values are means and standard deviations)

\begin{tabular}{lccccc}
\hline & & \multicolumn{2}{c}{$\begin{array}{c}\text { Carbohydrate } \\
(\mathrm{g} / \mathrm{kg})\end{array}$} & \multicolumn{2}{c}{$\begin{array}{c}\text { Lactose } \\
(\mathrm{g} / \mathrm{kg})\end{array}$} \\
\cline { 2 - 6 } $\begin{array}{l}\text { Gestational age } \\
\text { (weeks) }\end{array}$ & $n$ & Mean & SD & Mean & SD \\
\hline $25-26$ & 57 & 74.6 & 3.6 & 58.5 & 4.7 \\
27 & 75 & 74.3 & 5.2 & 59.2 & $4.2 \dagger$ \\
28 & 70 & 71.4 & $4.9^{\star}$ & 56.9 & 7.2 \\
29 & 79 & $72 \cdot 2$ & 5.0 & 58.3 & $4.9 \ddagger$ \\
$25-29$ & 281 & 73.0 & 4.9 & 58.2 & $5 \cdot 4$ \\
\hline
\end{tabular}

* Mean value was significantly different from that for GA of 25-26 weeks $(P<0.001)$ and from that for $\mathrm{GA}$ of 27 weeks $(P<0.02)$. $+n 76$.

$\ddagger n 78$.

analysis. In this way we were able to correct for interindividual as well as intra-individual variability. Moreover, in our study, possible effects of $24 \mathrm{~h}$ volume on the observed differences in macronutrient concentrations between GA, PNA or PMA groups were controlled for by means of the statistical technique of covariance analysis.

\section{Effect of gestational age}

We found that total carbohydrate concentration was lower when the GA was higher (Table 4). When differences in composition of very preterm human milk are found to be related to the GA this indicates that the event of birth interrupts the gestational developmental processes occurring in the mammary gland, with a lasting effect on the composition of the milk produced. We have seen this only for the total carbohydrate content. An explanation for this might be that we only studied a small range of GA, a broader range from week 25 to 36 might have led to a different conclusion.

Taking into account that approximately $800 \mathrm{~g} / \mathrm{kg}$ carbohydrate in human milk is considered to be lactose, we could have expected an effect of GA for lactose as well. However, such an effect was absent (Table 4), possibly due to the relatively large variation in the lactose contribution to the carbohydrate content in our samples (640-930 g/ $/ \mathrm{kg}$ ).

\section{Effect of postnatal age}

Changes in composition related to PNA indicate that there is a relationship with the lactational processes (for example of the mammary gland) initiated at the moment of birth. Like other studies, we found similar postnatal changes in protein (Atkinson et al. 1978, 1980; Gross et al. 1980, 1981; Schanler \& Oh, 1980; Anderson et al. 1981; Lemons et al. 1982, 1983; Anderson et al. 1983; Butte et al. 1984; Lepage et al. 1984; Darwish et al. 1989; Dawodu et al. 1990) and lactose content (Gross et al. 1980; Anderson et al. 1981; Gross et al. 1981; Darwish et al. 1989; Dawodu et al. 1990). Similar postnatal changes are also seen in full-term milk (Atkinson et al. 1978, 1980; Gross et al. 1980, 1981; Anderson et al. 1981; Guerrini et al. 1981; Hibberd et al. 1982; Lemons et al. 1982, 1983; Anderson et al. 1983; Butte et al. 1984; Jain \& Bijlani, 1989; Dawodu et al. 1990; 
Lawrence, 1994), indicating that the compositions of both preterm and full-term human milk change in a similar way (Anderson, 1984). In our samples lactose content also changes relative to total carbohydrate content from $760 \mathrm{~g} / \mathrm{kg}$ by days $7-10$ to $800 \mathrm{~g} / \mathrm{kg}$ by days $29-32$ and $850 \mathrm{~g} / \mathrm{kg}$ by days 51-55 (Table 1), which is in accordance with what has been found in full-term human milk (Coppa et al. 1991, 1993).

\section{Effect of post-menstrual age}

Dependency of milk composition on PMA would imply that changes in milk composition are in accordance with developmental changes in the fetal-maternal unit. This could mean that the changes in milk composition are in accordance with the nutrient requirements of the infant at various developmental stages. We did not find such a 'teleological' relationship for any of the studied nutrients.

In conclusion, postnatal changes dominate the development of the composition of very preterm human milk. GA affects only carbohydrate content, with a minor net effect on the nutritional value of the milk.

\section{Acknowledgements}

First, we want to thank all mothers for their milk samples and cooperation throughout the study. We also thank J. A. Boerma from the laboratories of Nutricia, The Netherlands, for the chemical analyses of the samples. We are grateful to J. G. Koppe and R. de Leeuw for their support of this project. Also, we are grateful to the referee of the journal to which we submitted the paper previously, for critically reviewing the manuscript. Y. G. H. M. and J. G. were financially supported by Nutricia, The Netherlands. This report is part of a study in fulfilment of the Degree in Philosophy in Science for Y. G. H. M.

\section{References}

Anderson DM, Williams FH, Merkatz RB, Schulman PK, Kerr DS \& Pittard WB (1983) Length of gestation and nutritional composition of human milk. American Journal of Clinical Nutrition 37, 810-814.

Anderson GH (1984) The effect of prematurity on milk composition and its physiological basis. Federation Proceedings $\mathbf{4 3}$, $2438-2442$.

Anderson GH, Atkinson SA \& Bryan MH (1981) Energy and macronutrient content of human milk during early lactation from mothers giving birth prematurely and at term. American Journal of Clinical Nutrition 34, 258-265.

Atkinson SA, Anderson GH \& Bryan MH (1980) Human milk: comparison of the nitrogen composition in milk from mothers of premature and full-term infants. American Journal of Clinical Nutrition 33, 811-815.

Atkinson SA, Bryan MH \& Anderson GH (1978) Human milk: difference in nitrogen concentration in milk from mothers of term and premature infants. Journal of Pediatrics 93, 6769.

Beijers RJW, Graaf FVD, Schaafsma A \& Siemensma AD (1992) Composition of premature breast-milk during lactation: constant digestible protein content (as in full term milk). Early Human Development 29, 351-356.
Boerhinger Mannheim GmbH (1989) Methods of Biochemical Analysis and Food Analysis: Using Test-Combinations, pp. 8083. Mannheim, Germany: Boerhinger Mannheim GmbH.

Box GEP \& Cox DR (1964) Analysis of transformations. Journal of the Royal Statistical Society 26B, 211-252.

Butte NF, Garza C, Johnson CA, Smith EO \& Nichols BL (1984) Longitudinal changes in milk composition of mothers delivering preterm and term infants. Early Human Development 9. $153-162$.

Coppa GV, Gabrielli O, Pierani P, Catassi C, Carlucci A \& Giorgi PL (1993) Changes in carbohydrate composition in human milk over 4 months of lactation. Pediatrics 91, 637-641.

Coppa GV, Gabrielli O, Pierani P, Zampini L, Rotolli G, Carlucci A \& Giorgi PL (1991) Qualitative and quantitative studies of carbohydrates of human colostrum and mature milk. Rivista Italiana di Pediatria 17, 303-307.

Darwish AEH, Dakroury AM, El-Feel MS \& Nour NM (1989) Comparative study on breast milk of mothers delivering preterm and term infants. Protein, fat and lactose. Nahrung 33, 249-251.

Dawodu AH, Osibanjo O \& Damole IO (1990) Nutrient composition of milk produced by mothers of preterm infants in Nigeria. East African Medical Journal 67, 873-877.

Dixon WJ (editor) (1992) In BMDP Statistical Software Manual. Berkeley, Los Angeles and Oxford: University of California Press.

Dubowitz LMS, Dubowitz V \& Goldberg C (1970) Clinical assessment of gestational age in newborn infants. Journal of Pediatrics 77, 1-10.

Gross SJ, David RJ, Bauman L \& Tomarelli RM (1980) Nutritional composition of milk produced by mothers delivering preterm. Journal of Pediatrics 96, 641-644.

Gross SJ, Geller J \& Tomarelli RM (1981) Composition of breast milk from mothers of preterm infants. Pediatrics $\mathbf{6 8}$, 490-493.

Guerrini P, Bosi G, Chierici R \& Fabbri A (1981) Human milk: relationship of fat content with gestational age. Early Human Development 5, 187-194.

Helrich K (editor) (1990) In Official Methods of Analysis of the $A O A C, 15$ th ed. Arlington, VA: Association of Official Analytical Chemists Inc.

Hibberd CM, Brooke OG, Carter ND, Haug M \& Harzer G (1982) Variation in the composition of breast milk during the first 5 weeks of lactation: implications for the feeding of preterm infants. Archives of Disease in Childhood 57, $658-662$.

Hytten FE (1954) Clinical and chemical studies in human lactation. IV. Trends in milk composition during course of lactation. British Medical Journal 1, 249-253.

Jain S \& Bijlani RL (1989) The significance of some significant features of breast milk. Indian Journal of Physiology and Pharmacology 33, 118-128.

Lawrence PB (1994) Breast milk. Best source of nutrition for term and preterm infants. Pediatric Clinics of North America 41, 925-941.

Lemons JA, Moye L, Hall D \& Simmons M (1982) Differences in the composition of preterm and term human milk during early lactation. Pediatric Research 16, 113-117.

Lemons JA, Reyman D \& Moye L (1983) Amino acid composition of preterm and term breast milk during early lactation. Early Human Development 8, 323-329.

Lepage G, Collet S, Bouglé D, Kien LC, Lepage D, Dallaire L, Darling P \& Roy CC (1984) The composition of preterm milk in relation to the degree of prematurity. American Journal of Clinical Nutrition 40, 1042-1049.

Pamblanco M, Ten A \& Comin J (1986) Proteins in preterm and term milk from mothers delivering appropriate or 
small-for-gestational age infants. Early Human Development 14, 267-272.

Pierse P, Van Aerde J \& Clandinin MT (1988) Nutritional value of human milk. Progress in Food and Nutrition Science 12, 421-447.

Prechtl HFR (editor) (1984) Continuity of Neural Functions from
Prenatal to Postnatal Life. Clinics in Developmental Medicine, vol. 94. Oxford: SIMP/Blackwell.

Schanler RJ \& Oh W (1980) Composition of breast milk obtained from mothers of premature infants as compared to breast milk obtained from donors. Journal of Pediatrics 96, $679-681$. 